\title{
Why do floating structures create novel habitats for subtidal epibiota?
}

\author{
M. G. Holloway ${ }^{1, *}$, S. D. Connell ${ }^{2}$ \\ ${ }^{1}$ Centre for Research on Ecological Impacts of Coastal Cities, Marine Ecology Laboratories A11, University of Sydney, \\ New South Wales 2006, Australia \\ ${ }^{2}$ Department of Environmental Biology, University of Adelaide, Adelaide, South Australia 5005, Australia
}

\begin{abstract}
Urban structures are a conspicuous, yet poorly understood component of the marine environment along urban coastlines. Previous work has shown that different types of structures support different diversities and relative abundances of sessile marine organisms. Studies on the effects of substratum composition, age, orientation and the effects of predation have failed to explain the observed differences in assemblages that develop on different types of structures. We assessed the model that differences in epibiotic assemblages between pontoons and pilings were due to the floating nature of pontoons versus the fixed (relative to the seafloor) nature of pilings, as opposed to other structural differences (colour, shape, surface type, etc.). Two additional (nonmutually exclusive) models were also tested. These were that the presence of a 'swash zone' constantly exposed to wave action and/or attachment to the benthos could cause differences between pontoons and pilings. We hypothesized that purpose-built experimental structures that floated would develop different assemblages from structures that were held fixed relative to the seafloor, regardless of whether they were pontoons or pilings. If swash were important, then structures floating just below the surface would differ from structures floating at the surface. If attachment to the benthos were important, then pilings attached to the benthos would differ from all the other structures. Multivariate analyses supported the hypothesis that both floating and the presence of swash were important in creating a typical pontoon assemblage, while other factors (type of structure, attachment to the benthos) were not. Several taxa contributed to these differences, including the mussel Mytilus edulis, the polychaete tubeworm Hydroides sp. and several algal taxa. Differences between fixed and floating structures have implications for the interpretation of previous studies done on floating docks. More studies of this kind are needed in order to inform the managers of urban waterways about the implications of adding different types of structures to the coastal environment.
\end{abstract}

KEY WORDS: Artificial habitats $\cdot$ Recruitment $\cdot$ Fouling $\cdot$ Urban ecology

\section{INTRODUCTION}

The study of urban environments as ecological habitats has been recognized as an important and emerging priority for ecologists (McDonnell \& Pickett 1990, Pickett et al. 1997). Most of the world's population live in urban habitats, particularly on the coast (Hammond 1992), and understanding the ecology of urban habi-

*E-mail: mhollowa@bio.usyd.edu.au tats is arguably just as important to the management of human activities as understanding the ecology of socalled 'natural' habitats. One very real aspect of urbanisation is that urban structures act as habitats for a diverse suite of organisms, but surprisingly little is known about their ecology (Glasby \& Connell 1999). Relative to other aspects of urbanisation (pollution, dumping, dredging, recreational activities), ecologists have invested little effort in understanding urban structures as habitats. 
In marine systems, rocky reef is the primary habitat for a diverse set of marine biota (Moore \& Seed 1986, Womersley 1987, Shepherd \& Davies 1997), for which urban structures act as surrogate habitats (e.g. Connell 1999, 2000, Glasby 1999a). Pilings and pontoons are common to estuarine and coastal areas throughout the world because they facilitate large-scale commercial and recreational boating. Recent studies show that these structures represent novel habitats for subtidal epibiota because the diversities and abundances of epibiota develop differently between these habitats and rocky reef (pontoons $\neq$ pilings $\neq$ rocky reef) (Connell 2001a).

The addition of pilings and pontoons to coastal waterways has created human-generated heterogeneity. New and novel substrata provided by horizontal, floating surfaces of pontoons and tall vertical surfaces of pilings represent substantially different habitats from natural hard substrata like rocky reef. Such heterogeneity creates or removes opportunities for organisms and influences biological diversity (Connell \& Glasby 1999). Processes that generate new habitats can cause assemblages to change in structure and composition. Furthermore, urban structures may become habitats for introduced species. For example Keough \& Ross (1999) identified 51 introduced species or likely introductions that occur on artificial structures in southeastern Australia. Such novel assemblages on artificial structures may, in turn, affect the distribution and abundance of pelagic taxa such as fishes (LopezJamar et al. 1984, Caine 1987).

It is not yet understood why the development of epibiotic assemblages differs among pontoons, pilings and reefs. Differences in composition and age of the substratum appear to be an obvious factor because the composition of pilings (often wood), pontoons (often plastic or fibreglass) and rocky reef (sandstone) are so strikingly different. Experimental tests using surfaces of standard age and composition, however, failed to explain differences in assemblages (Connell 2001a). Furthermore, comparison of sandstone versus concrete surfaces between pontoons and rocky reef revealed that composition of substratum explains very little (Connell 2000). Models about greater predation by fishes on pilings than on pontoons also do not account for differences between these habitats. Epibiotic assemblages developed in ways more consistent with differences in habitat than predation (Connell 2001b). The effects of oscillatory movement of surfaces due to currents and wave action caused different assemblages on fixed versus moving surfaces, but could not fully explain differences between fixed and floating structures (Glasby 2001).

One obvious factor remains to be assessed: the fact that pontoons float and spend greater amounts of time at the sea surface than pilings. The ecology of floating structures may differ profoundly from that of fixed structures and this may obliterate any effects due to size, shape, age and composition of habitat. Although the floating nature of pontoons is a potential explanation, an experiment is required to separate it from competing models about mechanisms that cause floating structures to have a substantially unique set of sessile epibiotic assemblages (Connell 2000, 2001a).

This study used 3 approaches: (1) We hypothesized that epibiotic assemblages develop differently on floating than fixed surfaces independent of their size, composition and shape (i.e. cubic, plastic or fiberglass pontoons versus cylindrical, wooden pilings) and therefore the floating versus the fixed nature of these structures could explain observed differences. (2) We assessed processes that may explain why epibiotic assemblages differ between fixed and floating structures. One major difference between fixed pilings and floating pontoons is that floating structures are largely isolated from the seafloor whereas pilings are connected to the seafloor; this difference in connectivity with the benthos may cause large differences in processes associated with the seafloor (e.g. benthic predators do not have the same access to pontoons as to pilings). (3) We examined the effects of swash on the assemblages, a second difference between these structures being that the subtidal surfaces of pontoons are continuously exposed to surface swash (sensu Komar 1976) because they are constantly positioned at the sea surface, whereas the subtidal surfaces of pilings experience swash only at low tide; swash can affect the structure of assemblages of some marine biota (McArdle \& McLachlan 1992).

\section{MATERIALS AND METHODS}

Study area and experimental treatments. The study was done from March to December 2000 at Cockatoo Island and Goat Island situated $2.5 \mathrm{~km}$ apart in the western part of Sydney Harbour, Australia (33 $48^{\prime} \mathrm{S}$, $151^{\circ} 14^{\prime}$ E: Fig. 1 ; tidal range $\approx 2 \mathrm{~m}$ ). The 2 islands were used as replicate sites to provide a preliminary test of spatial generality of results from a single site. At each site, experimental units of different treatments (described below) were haphazardly interspersed (3 to $5 \mathrm{~m}$ apart) alongside existing jetties for a period of 9 mo. There were 3 replicate experimental units for each treatment at each site:

Floating versus fixed structures: If the floating nature of pontoons versus the fixed nature of pilings causes epibiotic assemblages to differ, we predicted that the epibiotic assemblages that develop on floating structures (pilings and pontoons) would differ from 


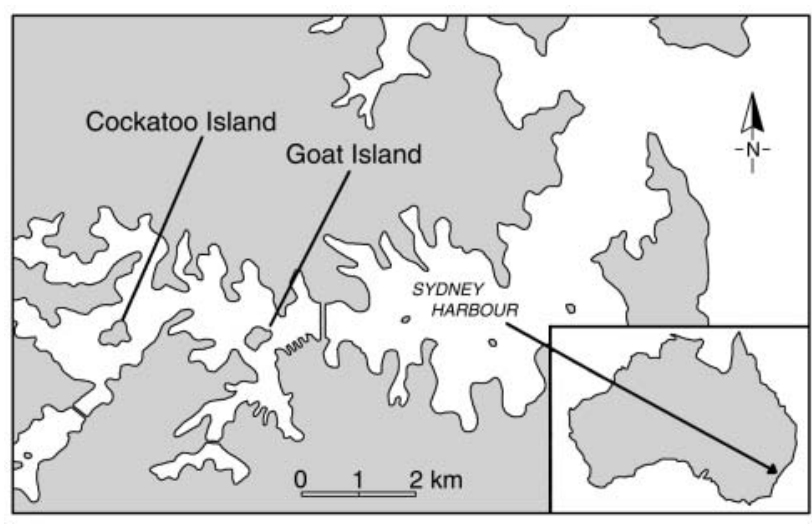

Fig. 1. Map showing locations of study sites within Sydney Harbour, Australia

those held fixed relative to the seafloor (pilings and pontoons) independent of shape and size. Furthermore, there would be no differences between structures (pilings and pontoons) within floating or fixed treatments.

Floating pilings were made from wooden pilings commonly found in Sydney Harbour $(0.3 \mathrm{~m}$ diameter $\times$ $0.7 \mathrm{~m}$ long) that were hollowed out and filled with buoyancy foam (moulded polystyrene and polyurethane foaming resin). Pilings were held in a horizontal position by eyelets that guided the piling up and down 2 vertically opposed ropes attached to weights on the seafloor (below pilings) and a jetty (above pilings). Floating pontoons were made from plastic tubs $(0.41 \mathrm{~m}$ wide $\times 0.65 \mathrm{~m}$ long $\times 0.4 \mathrm{~m}$ deep) suspended from a jetty with 2 ropes through the extreme opposite sides of the pontoon to weights hanging in mid-water. Flotation was provided by moulded polystyrene foam balls attached to the insides of the pontoons. Fixed pilings and pontoons were of exactly the same construction, but lacked flotation and were anchored in a position level with floating structures at mean low-water spring, MLWS (Fig. 2). The maximum vertical difference between fixed and floating structures was $2 \mathrm{~m}$ at high tide.

Attached versus isolated structures: If floating and fixed structures differ because fixed structures are attached to the seafloor and floating structures are isolated from the seafloor, we predicted that the epibiotic assemblages that developed on pilings attached to the seafloor would differ from that on pilings isolated from the seafloor. Pilings were constructed from the same materials as described above. We compared pilings fastened to existing pilings by rope (fixed attached pilings, ' 6 ' in Fig. 2) to pilings suspended a fixed distance from, but not attached to, the seafloor (fixed pilings, ' 4 ' in Fig. 2).
Much swash versus little swash: If greater swash against pontoons explains why their assemblages differ from those on pilings, we predicted that the epibiota on submerged floating pontoons (little swash) would develop differently from that on normal floating pontoons that have a swash zone extending some distance above the water's surface (much swash). Submerged floating pontoons were constructed of the same materials described above, but were suspended just below the water's surface by spherical polystyrene floats (' 5 ' in Fig. 2). We compared these with floating structures that had a swash zone of approximately $15 \mathrm{~cm}$ above the sea surface ('1 and 2' in Fig. 2).

Quantification of percentage cover. After $9 \mathrm{mo}$, each replicate structure was sampled in situ and abundances of benthic invertebrates and macro-algae were estimated. Primary cover (organisms attached directly to the structure) and secondary cover (organisms attached to primary cover) were estimated for sessile organisms on each of 2 vertical sides of structures using 64 regularly spaced points within a $27 \times 27 \mathrm{~cm}$ grid. Taxa on the sides of structures, but not under a measuring point, were assigned a cover of $0.5 \%$. At Cockatoo Island, serpulid polychaetes Hydroides sp. formed a thick, dense mat over many of the experimental structures, so percentage cover measurements may not accurately reflect their true abundance. Therefore, we also measured the thickness of the serpulid mat by pushing a metal rod through it and measuring the depth of penetration at 3 random points on each experimental unit. One replicate of the floating piling treatment was lost from each site and analyses were adjusted accordingly (see following subsection).

Analytical methods. Data were standardised by converting raw data to percentages for all multivariate and univariate tests. Both primary and secondary cover values were included in the analyses. Data were fourthroot-transformed prior to all multivariate analyses to allow rarer taxa a relatively greater contribution to the

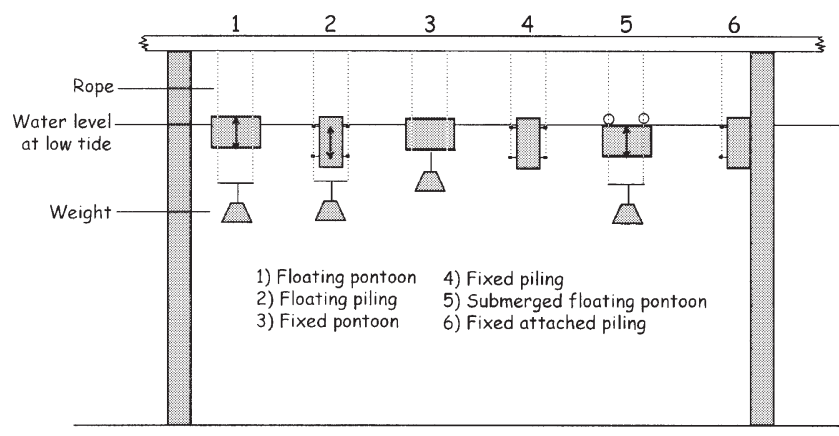

Fig. 2. Details of experimental treatments. Experimental structures are shown in their relative vertical positions at low tide (mean low-water spring). Structures with arrows float and would therefore move upwards with the flooding tide 
Table 1. Results of 1-way NP-MANOVA on the effect of type of substrate structure 'Treatment' on the composition of associated epibiotic assemblages after 9 mo

\begin{tabular}{|lrrrrrrr|}
\hline \multirow{2}{*}{ Source } & df & \multicolumn{3}{c}{ Goat Island } & \multicolumn{3}{c|}{ Cockatoo Island } \\
& & SS & $F$ & p & SS & $F$ & $p$ \\
\hline Treatment & 5 & 18729 & 3.2 & 0.0002 & 12798 & 2.5 & 0.002 \\
Residual & 28 & 32394 & & & 28127 & & \\
\hline
\end{tabular}

software package (Clarke 1993). Data were fourth-root-transformed and a dissimilarity matrix constructed using the Bray-Curtis measure (Bray \& Curtis 1957). Multivariate analysis used the non-parametric multivariate ANOVA (NP-MANOVA: Anderson 2001, McArdle \& Anderson 2001) method modified to deal with unequal sample sizes. For the test of the hypothesis of differoutcome. In order to have sufficient replicate observations within sites for multivariate permutation tests, it was necessary to pool all replicate quadrats from each type of structure. To ensure that such pooling was valid, we first calculated the average Bray-Curtis dissimilarity between pairs of quadrats from the same experimental unit within each treatment, and contrasted these with the average of the dissimilarities between pairs of experimental units in each treatment (averaging the 2 quadrats within an experimental unit). This is analogous to checking for non-significant effects due to a nested factor before pooling its levels in a univariate ANOVA. There were no significant differences (Student's t-tests, $\mathrm{p}>0.25, \mathrm{n}=3$, except in 1 case where $0.05<\mathrm{p}<0.25$ ) between any of the within- and among-unit dissimilarities, justifying the pooling procedure.

Multivariate differences among treatments were visualised using the nMDS routine in the PRIMER

a) Both sites (centroids)

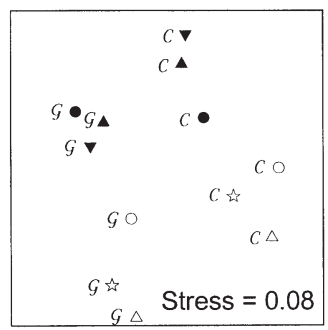

b) Goat Island

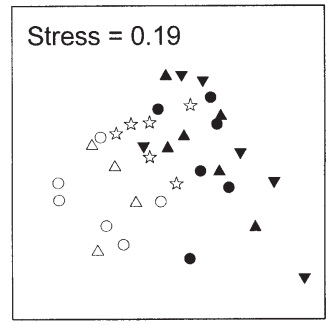

Fig. 3. nMDS plot of assemblages on experimental units at (a) both sites (centroids only are shown), (b) Goat Island and (c) Cockatoo Island ences among treatments, a 1-factor NP-MANOVA with 4999 permutations was done. Differences among treatments within each site were tested using multiplecomparison tests, each with 462 permutations. Because assemblages differed considerably among sites, we analysed the data for each site separately.

Univariate ANOVAs were done for taxa that contributed more than $10 \%$ of the dissimilarity among groups at each site, as determined using the SIMPER routine in PRIMER. Missing observations in the piling treatment were replaced with the average of the remaining replicates to balance the analyses, and degrees of freedom for the F-tests were adjusted accordingly (Underwood 1997). ANOVAs were of a 2 -factor nested design with experimental unit nested within treatment. Where the effect due to experimental unit was not significantly different from 0 (at $p>0.25)$ we pooled the replicates within each level (Underwood 1997). Data were transformed where necessary to meet the assumption of homogeneity of variances as evaluated by Cochran's test.

\section{RESULTS}

Twenty-three taxa and bare space were identified on the experimental structures and used in the multivariate analyses. The structures were initially colonised by serpulid polychaetes Hydroides sp. and then a range of epibiotic organisms, including mussels Mytilus edulis, encrusting and arborescent bryozoans, colonial ascidians, sponges and algae over the ensuing months. Multivariate analyses revealed clear differences among assemblages at different sites and among fixed and floating treatments (Fig. 3a, Table 1).

At Goat Island, floating structures appeared to support assemblages that differed from those on fixed structures (Fig. 3b). Post-hoc non-parametric multivariate multiple comparisons revealed that floating versus fixed structures and the presence of a swash zone were both important determinants of the assemblage structure. That is, fixed structures all had similar assemblages, but these differed from assemblages on floating structures. Among the 3 types of floating structure, those with swash (pilings and pontoons) were dif- 
Table 2. Bray-Curtis dissimilarities (\%) between assemblages on different types of structure. Bold values indicate that assemblages were significantly different (as determined by post-hoc multivariate test following NP-MANOVA, $\alpha=0.05$ ). Treatments were 1: floating pontoon, 2: floating piling, 3: fixed pontoon, 4: fixed piling, 5: floating submerged pontoon, 6: fixed attached piling

\begin{tabular}{|c|c|c|c|c|c|c|c|c|c|c|c|c|c|}
\hline & \multicolumn{6}{|c|}{ Goat Island } & & \multicolumn{6}{|c|}{ Cockatoo Island } \\
\hline & 1 & 2 & 3 & 4 & 5 & 6 & & 1 & 2 & 3 & 4 & 5 & 6 \\
\hline 1 & - & & & & & & - & & & & & & \\
\hline 2 & 44 & - & & & & & 38 & - & & & & & \\
\hline 3 & 62 & 62 & - & & & & 56 & 52 & - & & & & \\
\hline 4 & 63 & 60 & 48 & - & & & 52 & 52 & 52 & - & & & \\
\hline 5 & 50 & 45 & 45 & 47 & - & & 38 & 24 & 48 & 44 & - & & \\
\hline \multirow[t]{2}{*}{6} & 70 & 66 & 54 & 51 & 56 & - & 54 & 55 & 50 & 48 & 48 & - & \\
\hline & & \multicolumn{5}{|c|}{$1=2 \neq 3=4=6 \neq 5$} & \multicolumn{7}{|c|}{ No alternative to null hypothesis } \\
\hline
\end{tabular}

ferent from the structure without an emergent swash zone (Table 2). Thus the hypotheses that substrate position (floating vs fixed structures) and the presence of swash result in differences in assemblage structure between pontoons and pilings are supported. Inspection of the nMDS plot indicates that in addition to being different, assemblages on submerged floating pontoons were much less variable than those on the other structures without swash (Fig. 3b).

At Cockatoo Island, the pattern of differences among treatments was less clear (Fig. 3c). There were significant differences among the treatments, but pair-wise multiple comparison tests were unable to identify an alternative to the null hypothesis (of no difference among treatments). NP-MANOVA did, however, detect a significant difference between fixed and floating structures $(p=0.002)$. Floating pilings and submerged floating pontoons showed very little variability among replicates relative to the other treatments (Fig. 3c). Floating pontoons showed similar amounts of variability to fixed treatments. Assemblages on fixed pilings fell into 2 groups. Inspection of the data suggested that this was most likely due to a brown diatomaceous film, which was more abundant on one side of the structures than on the other.

At Goat Island, 6 variables each contributed at least $10 \%$ to the overall differences among groups (SIMPER analysis). There were significant differences among treatments for Hydroides sp., Mytilus edulis, the brown alga Dictyota dichotoma and botryllinid ascidians (Table 3). M. edulis were more abundant on floating pilings and pontoons than on all other treatments. Floating pilings and pontoons also differed from one another, with significantly greater cover of $M$. edulis on pontoons than pilings (Fig. 4b). For the other taxa, differences detected by ANOVA could not be resolved (Student-Newman Keuls, SNK, tests), but some may have been associated with (1) sparser cover of tubeworms on floating structures with swash (Treatments 1 and 2: Fig. 4a), (2) botryllinid colonies having sparser cover on floating structures (Fig. 4d), and (3) D. dichotoma having more extensive cover on floating structures than on fixed structures (Fig. 4c).

At Cockatoo Island, 7 variables each contributed at least $10 \%$ to the overall dissimilarity among treatments (SIMPER analysis). Differences in percentage cover

Table 3. Goat Island: summaries of ANOVA results for taxa that were important in discriminating among treatments in multivariate analyses (as determined by SIMPER analysis). Bold values indicate significant differences

\begin{tabular}{|c|c|c|c|c|c|c|c|}
\hline Source & $\mathrm{df}$ & MS & $F$ & $\mathrm{p}$ & MS & $F$ & $\mathrm{p}$ \\
\hline & & \multicolumn{3}{|c|}{ (a) Hydroides sp. } & \multicolumn{3}{|c|}{ (b) Bare space } \\
\hline Treatment & 5 & 2657 & 3.94 & 0.027 & 52.19 & 0.74 & 0.609 \\
\hline Pontoon (Treatment) & 11 & 675 & 2.46 & 0.050 & 70.49 & 1.50 & 0.224 \\
\hline Residual & 16 & 274 & & & 46.92 & & \\
\hline & & \multicolumn{3}{|c|}{ (c) Mytilus edulis } & \multicolumn{3}{|c|}{ (d) Botryllinid ascidians ${ }^{\mathrm{a}}$} \\
\hline Treatment & 5 & 2968 & 35.8 & 0.000 & 2.66 & 2.99 & 0.028 \\
\hline \multirow[t]{2}{*}{ Residual } & 27 & 83 & & & 0.89 & & \\
\hline & & \multicolumn{3}{|c|}{ (e) Dictyota dichotoma } & \multicolumn{3}{|c|}{ (f) Filamentous algae } \\
\hline Treatment & 5 & 532 & 6.91 & 0.000 & 64.52 & 1.81 & 0.144 \\
\hline Residual & 27 & 77 & & & 35.68 & & \\
\hline
\end{tabular}



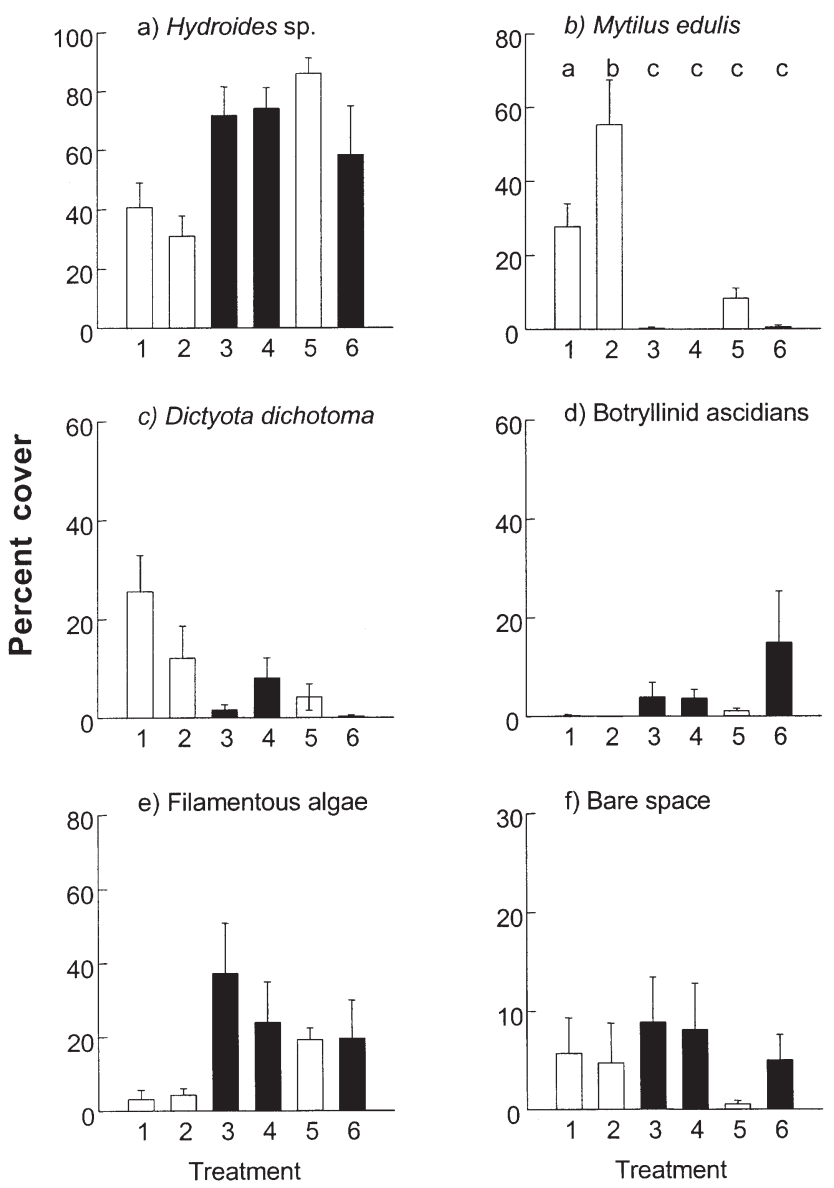

Fig. 4. Goat Island: percentage cover (mean $\pm \mathrm{SE}$ ) of important variables on experimental structures. White bars indicate floating structures; black bars fixed structures. Odd-numbered treatments are pontoons and even numbers are pilings; Treatment 5 is floating subsurface pontoon; Treatment 6 is fixed attached piling. See 'Materials and methods' and Fig. 2 for further details of treatments. Letters above bars in (b) represent results of SNK tests: treatments with same letter are not significantly different at $\alpha=0.05$ among treatments were significant for 5 of these, although SNK tests could not resolve differences among treatments for any variable. Differences detected by ANOVA appear to relate to greater cover of Hydroides sp. on floating than fixed structures (Fig. 5a). This pattern was much more obvious when the thickness of the Hydroides sp. layer was analysed $\left(F_{5,11}=8.18, \mathrm{p}=0.002\right.$, see Fig. $\left.5 \mathrm{~b}\right)$. M. edulis were present only on floating structures with swash, but in very small numbers (Fig. 5c). Filamentous algae were also more abundant on floating than on fixed structures (Fig. 5h). Bugula neritina and bare space appeared to be more abundant on fixed structures than on floating structures (Fig. 5g,d, respectively).

\section{DISCUSSION}

The most striking result of this study was the clear difference between fixed and floating structures at both sites. This pattern emerged despite considerable differences between sites in the sessile assemblages that developed. The results from Goat Island clearly support the hypothesis that both flotation (rather than permanence) and the presence of an emergent swash zone are necessary for the development of a typical pontoon assemblage. Furthermore, structure of the substratum (pontoon vs piling), particular material type (wood vs plastic) and connection to the substratum are not necessary for the development of such assemblages. Results from Cockatoo Island were not so clear, with post-hoc tests unable to identify an alternative to the null hypothesis, but the same general trend for differences among treatments is apparent from the nMDS plot (Fig. 3). Several individual taxa contributed to the multivariate differences, and these showed patterns of difference among treatments.

Table 4. Cockatoo Island: summaries of ANOVA results (as determined by SIMPER analysis) for taxa that were important in discriminating among treatments in multivariate analyses. Bold values indicate significant differences

\begin{tabular}{|c|c|c|c|c|c|c|c|}
\hline Source & $\mathrm{df}$ & MS & $F$ & $\mathrm{p}$ & MS & $F$ & $\mathrm{p}$ \\
\hline & & \multicolumn{3}{|c|}{ (a) Hydroides sp. } & \multicolumn{3}{|c|}{ (b) Mytilus edulis } \\
\hline Treatment & 5 & 1098 & 2.67 & 0.043 & 30.6 & 3.37 & 0.017 \\
\hline Residual & 27 & 411 & & & 9.08 & & \\
\hline & & \multicolumn{3}{|c|}{ (c) Bare space } & \multicolumn{3}{|c|}{ (d) Botrylloides leachii } \\
\hline Treatment & 5 & 972 & 2.63 & 0.046 & 19.58 & 0.73 & 0.608 \\
\hline Residual & 27 & 370 & & & 26.88 & & \\
\hline & & \multicolumn{3}{|c|}{ (e) Diatomaceous film } & \multicolumn{3}{|c|}{ (f) Bugula neritina } \\
\hline Treatment & 5 & 163 & 1.37 & 0.268 & 260.7 & 3.67 & 0.012 \\
\hline Residual & 27 & 119 & & & 71.04 & & \\
\hline \multicolumn{8}{|c|}{ (g) Filamentous algae } \\
\hline Treatment & 5 & 5758 & 4.31 & 0.005 & & & \\
\hline Residual & 27 & 1336 & & & & & \\
\hline
\end{tabular}


Previously observed differences between assemblages on fixed and floating structures in Sydney Harbour have been caused by a range of taxa, but most consistently by Mytilus edulis and colonial ascidians (more abundant on floating structures), and spirorbid polychaetes (more abundant on fixed structures) (Connell 2000, 2001a, Glasby \& Connell 2001). In this study, $M$. edulis showed patterns consistent with previous studies, and followed a pattern similar to that of the differences among assemblages on different treatments at Goat Island (Fig. 4). Spirorbids did not recruit in sufficient numbers for analysis, and patterns for colonial ascidians were inconsistent between sites in this study.

Fixed and floating subtidal structures differ in a number of physical characteristics, which may explain why their assemblages differ. Floating structures experience a constant depth and are constantly exposed at the water's surface, whereas fixed substrata are exposed to a range of depths and may only encounter the surface during low tides. One important ecological factor that could cause different assemblages is light. Fixed subtidal habitats would experience fluctuating light intensities, varying with the state of the tide, whereas floating structures would experience relatively greater and more constant light intensity by virtue of their position near the surface. Light has been shown to affect the structure of assemblages on artificial substrata (Glasby 1999b). Light is an important determinant of larval behaviour and the distribution of recruits (e.g. Thorson 1964, Forward et al. 2000, Saunders \& Connell 2001) and can also influence the distribution and growth of algae (Markager \& Sand-Jensen 1992, Duarte \& Ferreira 1995, Glasby 1999b).

A second mechanism that could cause different assemblages on fixed and floating structures is recruitment by depth-stratified larvae. Floating structures would be more likely to encounter larvae that concentrate close to the surface than fixed structures. Fixed structures, on the other hand, would encounter more larvae that occur at greater depth. McDougal (1943) found that barnacles Balanus eberneus recruited in greater numbers on a fixed pile than on a floating one. This was attributed to the barnacle larvae being concentrated at $2.5 \mathrm{~m}$ below the surface (and thus below the bottom of the floating pile at all times). Other studies on the distribution of cyprids indicate that they can be depth-stratified and that this can explain the vertical distribution of recruits on fixed structures (Grosberg 1982, Miron et al. 1995, 1999). Studies on the recruitment of mussels to floating structures have reported greater recruitment at shallower depths, suggesting that larvae may be more concentrated near the surface (Fuentes \& Molares 1994, Cáceres-Martínez \& Figueras 1997, but see
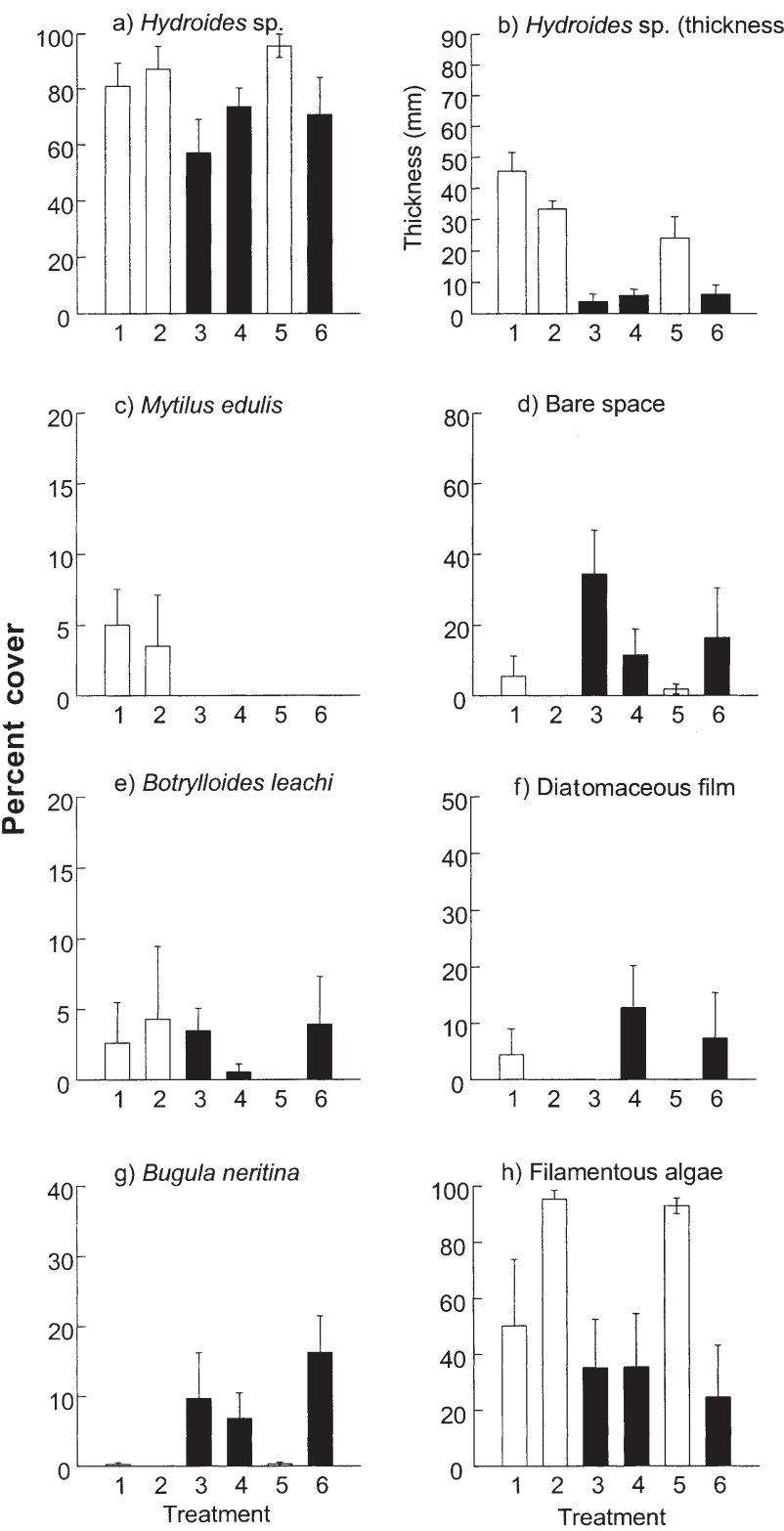

Fig. 5. Cockatoo Island: abundance of important variables on experimental structures. Abundance measured as percentage cover except where indicated. Treatments as in Fig. 4

Cáceres-Martínez \& Figueras 1998). This could explain why we found greater abundances of Mytilus edulis on floating structures.

Assemblages on floating subsurface pontoons differed (more serpulid polychaetes, fewer mussels, more filamentous algae) from those on floating structures with swash. They were also less variable on the former. The processes causing these differences are unclear, but we propose 2 models. The first is connected with hydrodynamic effects. The flow of water around emergent and submerged floating substrata may be very different. Different hydrodynamic conditions may dif- 
ferentially favour the recruitment and/or growth of different species, leading to different final assemblages (Eckman \& Duggins 1991, Abelson \& Denny 1997). An alternative model explaining the difference between subsurface and emergent substrata could be related to the assemblage that developed on the emergent section. This assemblage included mobile grazing gastropods that were not present on fully submerged structures (Holloway pers. obs.); these snails could influence the development of the submerged assemblages. Such grazers have been shown to influence the development of epibiotic assemblages, either directly by removing juvenile stages, or indirectly by removing algae that may compete with sessile animals (Turner \& Todd 1991, Anderson \& Underwood 1997).

Connection to the benthos, potentially allowing access to structures by benthic predators, was unimportant in determining the structures of sessile assemblages in this study. Keough \& Butler (1979) found that benthic predators had no discernible effect on pier piling communities. In contrast, other authors have found effects on a range of taxa including barnacles, mussels, oysters, bryozoans and hydroids (Karlson 1978, Harris \& Irons 1982, Brown \& Swearingen 1998). Allmon \& Sebens (1988) found strong effects of an introduced nudibranch, but only on a particular soft coral species. Benthic predators may be unimportant in this system, but effects of pelagic predators cannot be ruled out. Fan-bellied leather jackets Monacanthus chinensis and yellow fin bream Acanthopagrus australis were observed feeding around pilings at Cockatoo Island, but never at the surface. Connell (2001b) was, however, unable to detect differences in predation on epibiota between pilings and pontoons by abundant, predatory fishes.

Recent work has demonstrated that the development of epibiotic assemblages differs most between pontoons compared with adjacent pilings and rocky reef (Connell 2001a). Pontoons tend to create novel habitats for epibiotic assemblages regardless of the age and composition of the substratum (Connell 2001a, and present paper). These results are strikingly at odds with a substantial number of studies showing age and composition of the substratum to be important determinants of the types and abundances of epibiotic organisms within a habitat (e.g. Menge \& Sutherland 1976, McGuinness 1989, Anderson \& Underwood 1994, Underwood \& Anderson 1994). It appears that differences in habitats that epibiota occupy (e.g. pontoons vs pilings vs rocky reef) can over-ride the effects of the composition and history of the substratum.

Many studies have examined processes such as settlement, recruitment and development of sessile assemblages using artificial substrata suspended from floating structures (e.g. Dean \& Hurd 1980, Dean 1981,
Greene \& Schoener 1982, Hurlbut 1991, Osman \& Whitlatch 1995a,b, Nandakumar 1996, Holm et al. 1997). Care must be taken in extrapolating the results of these studies to assemblages on fixed structures or habitats. Our results warn that lessons learnt from work done in floating habitats may explain very little of the overall variance in distribution and abundance of epibiota on fixed structures (see also Glasby 2001). While understanding and accounting for patterns of abundances of epibiota within urban structures has provided considerable insights to marine ecology as a discipline (e.g. Osman 1977, Sutherland \& Karlson 1977, Keough 1984), the capacity for such research to account for the ecology of assemblages on rocky reefs is unclear and questionable (Glasby \& Connell 2001).

As the human population grows and urban areas expand, it is inevitable that more artificial structures of various types will be built in urban waterways, further modifying their ecology. Therefore, understanding how and why biological assemblages on fixed and floating structures differ from one another will provide key information to assist in managing urban waterways. We have shown here that floating structures such as pontoons promote the development of assemblages that are significantly different from those on fixed structures. Furthermore, the nature of the habitat (fixed vs floating) is far more important in determining the nature of the assemblage than is the composition of the substratum. Information provided by studies of this type will better inform managers of urban waterways who must make decisions about where and what type of structures are added to the coastal environment.

Ecologists have some difficulty in accepting that studies of urban habitats contribute to ecological theory. Such studies have been considered to test ecological hypotheses using convenient but 'unnatural habitats'. These habitats, however, also represent a growing modification to our so-called 'natural habitats', and warrant study as ecological habitats in their own right. Ecologists tend to suspect the value of such studies because we are unsure how the lessons learnt from highly modified habitats apply elsewhere. Unfortunately, this attitude diminishes the value of understanding the ecology of habitats within which a disproportionately large number of the human world lives coastal cities. More than half the world's population lives on the coast, yet marine ecologists in particular continue to study habitats other than those in their backyard. If ecologists are still concerned as to whether their science is relevant to contemporary society (Peters 1991), then there might be some value in realising that we can contribute an ecological understanding to the management of our urban environment. 
Acknowledgements. This research was funded by the Australian Research Council through the Centre for Research on Ecological Impacts of Coastal Cities. We thank Graham Housefield for assistance with the design of the experimental units; Katie O'Donnell, Melanie Bishop, Reuben Schmitt and Kotton Patterson for help with construction of artificial structures; and Reuben Schmitt, Mick Wirth and Bob Hunt for assistance in field. Special thanks to Dr. M. J. Anderson for providing the NP-MANOVA program. Professor A. J. Underwood and Dr. M. G. Chapman provided helpful discussions. The manuscript benefited greatly from comments by Professor Underwood and Drs. C. McKindsey and C. Olabarria.

\section{LITERATURE CITED}

Abelson A, Denny M (1997) Settlement of marine organisms in flow. Annu Rev Ecol Syst 28:317-339

Allmon RA, Sebens KP (1988) Feeding biology and ecological impact of an introduced nudibranch, Tritonia plebeia, New England, USA. Mar Biol 99:375-385

Anderson MJ (2001) A new method for non-parametric multivariate analysis of variance. Austral Ecol 26:32-46

Anderson MJ, Underwood AJ (1994) Effects of substratum type on the recruitment and development of an intertidal estuarine fouling assemblage. J Exp Mar Biol Ecol 184: $217-236$

Anderson MJ, Underwood AJ (1997) Effects of gastropod grazers on recruitment and succession of an estuarine assemblage $-\mathrm{a}$ multivariate and univariate approach. Oecologia 109:442-453

Bray JR, Curtis JT (1957) An ordination of the upland forest communities of Southern Wisconsin. Ecol Monogr 27:325-349

Brown KM, Swearingen DC (1998) Effects of seasonality, length of immersion, locality and predation on an intertidal fouling assemblage in the northern Gulf of Mexico. J Exp Mar Biol Ecol 225:107-121

Cáceres-Martínez J, Figueras A (1997) Mussel (Mytilus galloprovincialis Lamarck) settlement in the Ria de Vigo (NW Spain) during a tidal cycle. J Shellfish Res 16:83-85

Cáceres-Martínez J, Figueras A (1998) Mussel (Mytilus galloprovincialis Lamarck) colonization on artificial substrates in the Ria de Vigo of NW Spain. J Shellfish Res 17:153-157

Caine EA (1987) Potential effect of floating dock communities on a South Carolina estuary. J Exp Mar Biol Ecol 108: $83-91$

Clarke KR (1993) Non-parametric multivariate analyses of changes in community structure. Aust J Ecol 18:117-143

Connell SD (1999) Effects of surface orientation on the cover of epibiota. Biofouling 14:219-226

Connell SD (2000) Floating pontoons create novel habitats for subtidal epibiota. J Exp Mar Biol Ecol 247:183-194

Connell SD (2001a) Urban structures as marine habitats: an experimental comparison of the composition and abundance of subtidal epibiota among pilings, pontoons and rocky reefs. Mar Environ Res 52:115-125

Connell SD (2001b) Predatory fish do not always affect the early development of epibiotic assemblages. J Exp Mar Biol Ecol 260:1-12

Connell SD, Glasby TM (1999) Do urban structures influence local abundance and diversity of subtidal epibiota? A case study from Sydney Harbour, Australia. Mar Environ Res 47:373-387

Dean TA (1981) Structural aspects of sessile invertebrates as organizing forces in an estuarine fouling community. J Exp Mar Biol Ecol 53:163-180
Dean TA, Hurd LE (1980) Development of an estuarine fouling community: the influence of early colonists on later arrivals. Oecologia 46:295-301

Duarte P, Ferreira JG (1995) Seasonal adaptation and shortterm metabolic responses of Gelidium sesquipedale to varying light and temperature. Mar Ecol Prog Ser 121: $289-300$

Eckman JE, Duggins DO (1991) Life and death beneath macrophyte canopies: effects of understory kelps on growth rates and survival of marine, benthic suspension feeders. Oecologia 87:473-487

Forward RB, Welch JM, Young CM (2000) Light induced larval release of a colonial ascidian. J Exp Mar Biol Ecol 248:225-238

Fuentes J, Molares J (1994) Settlement of the mussel Mytilus galloprovincialis on collectors suspended from rafts in the Ria de Arousa (NW of Spain): annual pattern and spatial variability. Aquaculture 122:55-62

Glasby TM (1999a) Differences between subtidal epibiota on pier pilings and rocky reefs at marinas in Sydney, Australia. Estuar Coast Shelf Sci 48:281-290

Glasby TM (1999b) Effects of shading on subtidal epibiotic assemblages. J Exp Mar Biol Ecol 234:275-290

Glasby TM (2001) Development of sessile marine assemblages on fixed versus moving substrata. Mar Ecol Prog Ser 215:37-47

Glasby TM, Connell SD (1999) Urban structures as marine habitats. Ambio 28:595-598

Glasby TM, Connell SD (2001) Orientation and position of substratum have large effects on epibiotic assemblages. Mar Ecol Prog Ser 214:127-135

Greene CH, Schoener A (1982) Succession on marine hard substrata: a fixed lottery. Oecologia 55:289-297

Grosberg RK (1982) Intertidal zonation of barnacles: the influence of planktonic zonation of larvae on vertical distribution of adults. Ecology 63:894-899

Hammond A (1992) World resources 1992-1993: towards sustainable development. Oxford University Press, Oxford

Harris LG, Irons KP (1982) Substrate angle and predation as determinants in fouling community succession. In: Cairns J (ed) Artificial substrates. Ann Arbor Science Publishers, Ann Arbor, p 131-174

Holm ER, Cannon G, Roberts D, Schmidt AR, Sutherland JP, Rittschof D (1997) The influence of initial surface chemistry on development of the fouling community at Beaufort, North Carolina. J Exp Mar Biol Ecol 215:189-203

Hurlbut CJ (1991) Community recruitment: settlement and juvenile survival of seven co-occurring species of sessile marine invertebrates. Mar Biol 109:507-515

Karlson RH (1978) Predation and space utilization patterms in a marine epifaunal community. J Exp Mar Biol Ecol 31: $225-239$

Keough MJ (1984) Effects of patch size on the abundance of sessile marine invertebrates. Ecology 65:423-437

Keough MJ, Butler AJ (1979) The role of asteroid predators in the organization of a sessile community on pier pilings. Mar Biol 51:167-177

Keough MJ, Ross J (1999) Introduced fouling species in Port Phillip Bay. In: Hewitt CL, Campbell DJ, Thresher RE, Martin RB (eds) Marine biological invasions of Port Phillip Bay, Victoria. Centre for Research on Introduced Marine Pests. Technical Report No. 20. CSIRO Marine Research, Hobart

Komar PD (1976) Beach processes and sedimentation. Prentice-Hall, Englewood Cliffs, NJ

Lopez-Jamar E, Iglesias J, Otero JJ (1984) Contribution of infauna and mussel-raft epifauna to demersal fish diets. Mar Ecol Prog Ser 15:13-18 
Markager S, Sand-Jensen K (1992) Light requirements and depth zonation of marine macroalgae. Mar Ecol Prog Ser 88:83-92

McArdle BH, Anderson MJ (2001) Fitting multivariate models to community data: a comment on distance-based redundancy analysis. Ecology 82:290-297

McArdle SB, McLachlan A (1992) Sand beach ecology: swash features relevant to the macrofauna. J Coast Res 8:398-407

McDonnell MJ, Pickett STA (1990) Ecosystem structure and function along urban-rural gradients: an unexploited opportunity for ecology. Ecology 71:1232-1237

McDougal KD (1943) Sessile marine invertebrates of Beaufort, North Carolina. Ecol Monogr 13:321-374

McGuinness KA (1989) Effects of some natural and artificial substrata on sessile marine organisms at Galeta Reef Panama. Mar Ecol Prog Ser 52:201-208

Menge BA, Sutherland JP (1976) Species diversity gradients: synthesis of the roles of predation, competition, and temporal heterogeneity. Am Nat 110:351-369

Miron G, Boudreau B, Bourget E (1995) Use of larval supply in benthic ecology: testing correlations between larval supply and larval settlement. Mar Ecol Prog Ser 124:301-305

Miron G, Boudreau B, Bourget E (1999) Intertidal barnacle distribution: a case study using multiple working hypotheses. Mar Ecol Prog Ser 189:205-219

Moore P, Seed R (1986) The ecology of rocky coasts. Columbia University Press, New York

Nandakumar K (1996) Importance of timing of panel exposure on the competitive outcome and succession of sessile organisms. Mar Ecol Prog Ser 131:191-203

Osman RW (1977) The establishment and development of a marine epifaunal community. Ecol Monogr 47:37-63

Osman RW, Whitlatch RB (1995a) The influence of resident adults on recruitment: a comparison to settlement. J Exp Mar Biol Ecol 190:169-198

Editorial responsibility: Roger Hughes (Contributing Editor), Bangor, Wales, UK
Osman RW, Whitlatch RB (1995b) The influence of resident adults on larval settlement: experiments with four species of ascidians. J Exp Mar Biol Ecol 190:199-220

Peters RH (1991) A critique for ecology. Cambridge University Press, Cambridge

Pickett STA, Burch WR, Dalton SE, Foresman TW, Grove JM, Rowntree R (1997) A conceptual framework for the study of human ecosystems in urban areas. Urban Ecosyst 1: 185-199

Saunders RJ, Connell SD (2001) Interactive effects of shade and surface orientation on the recruitment of spirorbid polychaetes. Austral Ecol 26:109-115

Shepherd SA, Davies M (1997) Marine invertebrates of Southern Australia, Part III. Graphic Print Group, Adelaide

Sutherland JP, Karlson RH (1977) Development and stability of the fouling community at Beaufort, North Carolina. Ecol Monogr 47:425-446

Thorson G (1964) Light as an ecological factor in the dispersal and settlement of larvae of marine bottom invertebrates. Ophelia 1:167-208

Turner SJ, Todd CD (1991) The effects of Gibbula cineraria (L.), Nucella lapillus (L.) and Asterias rubens L. on developing epifaunal assemblages. J Exp Mar Biol Ecol 154: 191-214

Underwood AJ (1997) Experiments in ecology. Their logical design and interpretation using analysis of variance. Cambridge University Press, Cambridge

Underwood AJ, Anderson MJ (1994) Seasonal and temporal aspects of recruitment and succession in an intertidal estuarine fouling assemblage. J Mar Biol Assoc UK 74: $563-584$

Womersley HBS (1987) The marine benthic flora of Southern Australia, Part II. South Australian Government Printing Division, Adelaide

Submitted: April 24, 2001; Accepted: October 31, 2001 Proofs received from author(s): May 15, 2002 